\title{
EfFect Of Addition Of VOLATILE OILS from ClOVE, GINGer and Peppermint on PROLONGING the SHELF LIFE OF MINGED MEAT DURING COLD STORAGE
}

\author{
By \\ El-Gammal, Rania E. ${ }^{1}$ and Ramadan Afaf-Haniem M. ${ }^{2}$ \\ 1- Food Industries Dept., Fac. of Agriculture, Mansoura Univ., Egypt. \\ 2-Home Economics Dept., Fac. of Specific Education, Mansoura Univ., Egypt
}

\section{Research Joupnal Specific Education \\ Faculty of Specific Education \\ Mansoura University}

ISSUE NO. 24, JAN. 2012

$$
\text { مجلة بحوث التربية النوعية - جامعة المنصورة }
$$


Effect of Addition OF volatile Oils from Clove, Ginger and Peppermint 


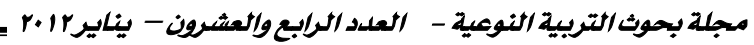

\section{EFFECT OF AddITION OF VOLATILE OILS fROM ClOVE, GINGER AND PEPPERMINT ON PROLONGING THE SHELF LIFE OF MINGED MEAT DURING COLD STORAGE}

By

El-Gammal, Rania E. ${ }^{1}$ and Ramadan Afaf-Haniem M. ${ }^{2}$.

1- Food Industries Dept., Fac. of Agriculture, Mansoura Univ., Egypt.

2-Home Economics Dept., Fac. of Specific Education, Mansoura Univ., Egypt

\section{Abstract}

This research was carried out to study the effect of addition volatile oils from natural herbs namely ginger, clove and peppermint on prolonging the shelf life of cold minced meat . Commercial raw minced beef meat was treated with extracted volatile oils at concentration of $1 \%$ and stored at 3$5^{\circ} \mathrm{C}$ for 10 days. Results of GC-MASS indicated that all extracted volatile oils from herbs under investigation contained a various amount of aromatic compounds, namely oxygenated, terpens, alcohols, esters and phenols, The most effective radical scavenging activity DPPH was detected in clove oil was $85.72 \%$ in compare with the added volatile oils. Color, $\mathrm{pH}$, Total Volatile Basis Nitrogen (TVB-N) and Thiobarbituric Acid Value (TBA) were determined..The meat beef samples treated with $1 \%$ (ginger oil + clove oil + peppermint oils ) showed the best colour, $\mathrm{pH}$, lowering protein hydrolysis and reducing lipid oxidation, prolonged storage period in compare with other treated minced beef meat and control samples . Total Bacterial Count (TBC) was decreased in beef meat samples treated with essential oils than those of the control meat. All samples showed good overall acceptability and still accepted for sensory properties up to 8 days of storage at $3-5^{\circ} \mathrm{C}$.

The obtained results indicated that aromatic compounds presented in volatile oils have high antioxidative effect in reducing the formation of secondary oxidation products and formation of ammonia during cold storage. So, It can be concluded that theses natural oils have potential effect to replace synthetic antioxidants which used in meat processing. 


\section{EfFEct Of Addition Of VOLATILE OILS from GlOVE, GINGER AND PEPPERMINT ON PROLONGING THE SHELF LIFE OF MINCED MEAT DURING COLD STORAGE}

By

El-Gammal, Rania E. ${ }^{1}$ and Ramadan Afaf-Haniem M. ${ }^{2}$.

1- Food Industries Dept., Fac. of Agriculture, Mansoura Univ., Egypt.

2-Home Economics Dept., Fac. of Specific Education, Mansoura Univ., Egypt

\section{INTRODUCTION}

Fresh meat products are commonly marketed at refrigerated temperatures $\left(2-5^{\circ} \mathrm{C}\right)$. However, many undesirable changes of the products can occur during refrigeration due to microbial growth and lipid oxidation, which give rise to quality reduction, meat spoilage, and economic loss .Minimizing product contamination and delaying or inhibiting growth of spoilage and pathogenic organisms in the product are major keys for improving fresh meat shelf- life and increasing consumer safety. While general cleanliness and proper sanitation are very effective, other means controlling of microbial growth in meat products is essential .

Minced meat is usually very perishable food so prolonging its shelf- life is an important objective for producers. The loss of meat freshness after mincing results mainly from the activity of endogenous and exogenous enzymes, (Fik et al ., 2008 )

There are many factors influencing meat shelf- life namely $\mathrm{pH}$, water content and availability of oxygen that could promote spoilage bacteria growth and oxidative processes during storage (Abril el al., 2001)

Lipid oxidation occurring in food products is one of the major concerns in food technology. It is responsible for rancid odors and flavors of the products, with a consequent decrease in nutritional quality and safety caused by the formation of secondary, potentially toxic compounds. The problem of ensuring a high quality of lipids and lipid-containing products and prolonging their storage time is directly associated with their optimum stabilization by addition of suitable antioxidants. This is very important to human health protection and also economically important. There is a growing interest in natural antioxidants found in plants because of the 
world-wide trend toward the use of natural additives in food and cosmetics. Herbs and spices are one of the most important targets to search for natural antioxidants from the point of view of safety . (Karpinska et al ., 2001)

Volatile oils are regarded as natural alternatives of chemical preservatives and their use in food meets the demands of consumers for mildly processed or natural products, since in modern food industries, mild processes are applied in order to obtain safe products which have a natural or "green" image (Burt, 2004). However, the practical application of essential or volatile oils are limited because of flavor considerations, as well as, their effectiveness is moderate due to their interaction with food ingredients and structure (Skandamis et al., 2001). Volatile oils or essential oils of herbs and their components, products from the secondary metabolism of plants, have many applications in ethno-medicine, food flavoring and preservation as well as the fragrance and pharmaceutical industries (Fasseas et al ., 2008).

Clove (Eugenia caryophyllata or Syzygium aromaticum) is an aromatic dried flour buds, it s native in Indonesia and used as a spice in foods, the whole essential oil or its main components is eugenol. Oil extracted from bud, stem and leaf, clove bud oil is the most expensive and best quality product (Hakki et al ., 2007)

Peppermint Mint Oil is oil derived from various mint varietals. The composition of the oil is dependent on the particular mint variety distilled. For instance, Peppermint's (Mentha piperita) oil is composed of Menthol, Menthone and Menthyl Acetate. Carvone and Limonene (Fabian et al ., 2006 ).

Ginger oil (Gingiben officinale) is produced from fresh or dried rhizomes. The phytochemicals of ginger consist of volatile oils bisabolene, cineol, phellandrene, citral, borneol, citronellol, geranial, linalool, limonene, zingiberol, zingiberene, camphene, oleoresin ,gingerol, phenol ,gingeol , zingerone, zingibain, some vitamins namely vitamin $\mathrm{B}_{6}$, vitamin $\mathrm{C}$, and some minerals calcium, magnesium, phosphorus and potassium.. The pungency of ginger is due to gingerol which is the alcohol group of the oleoresin can vary in color from pale yellow to darker amber color and the viscosity also ranges from medium to watery. It is a strong smelling oil-spicy, sharp, and warm. (Sasidharan and Nirmala, 2010) 
So, this paper aimed to study the possibility to extend the shelf life of minced meat beef treated with different volatile oils extracted from natural herbs namely ginger, clove and peppermint during cold storage at 3$5^{\circ} \mathrm{C}$ for 10 days with minimizing the changes in physical, chemical and sensorial properties of minced meat .

\section{MATERIALS AND METHODS}

\section{Materials-}

Fresh minced beef meat was obtained from local market- ElMansoura -Egypt.

Herbs : Dried Clove (Eugenia caryophyllata), Ginger( Gingiben officinale) and Peppermint (Mentha piperita) were purchased from El-Azhar, Cairo, Egypt .

\section{Chemicals : -}

DPPH (1.1 Diphenyl 1-2-picrylhydrazl ) was obtained from sigma/ Aldrich company .USA, and Sodium sulphate anhydrous was obtained from el-Gomhoria company for chemicals, El-Mansoura ,Egypt .

\section{Preparation of treated minced meat-}

Minced meat were divided into 7 bathes and mixed with different extracted essential oils as follows-

(a) $1 \%$ clove oil, (b) $1 \%$ ginger oil , (c) $1 \%$ peppermint oil (d) $0.5 \%$ clove oil $+0.5 \%$ ginger oil (e) $0.5 \%$ clove oil $+0.5 \%$ peppermint oil (f) $0.5 \%$ clove oil $+0.25 \%$ ginger oil $+0.25 \%$ peppermint oil .

-Treated minced meat were packed in fiber foam tray and stored in refrigerator at $3-5^{\circ} \mathrm{C}$ for 10 days, samples were taken every 2 days to evaluate the effect of different essential oils on the quality of cooled meat during storage.

\section{Analytical Methods -}

Moisture, protein, ash, fat and Total Volatile Basis TVB-N of minced meat were determined according to A.O.A.C. (2000).

PH values: were determined using $\mathrm{pH}$ meter model Jenway 3505 .U.K. according to A.O.A.C (2000). 
Colour : MetaMyoglobien MMb was determined in minced beef meat solution according to the method described by (Lee et al ., 1998 ) with optical density 700, 572, 525nm using Spekol 11, Carl Zeiss Jena, German at Faculty of Agriculture, Mansoura University . According the following equation -
Met $\mathrm{Mb} \%=1.395\left\{\left[\left(\mathrm{~A}_{\mathbf{5 7 2}}-\mathrm{A}_{\mathbf{7 0 0}}\right) /\left(\mathrm{A}_{\mathbf{5 2 5}}-\mathrm{A}_{\mathbf{7 0 0}}\right)\right]\right.$
$\left.x^{100}\right\}$
Where $A$ is the reading at 700,572 and $525 \mathrm{~nm}$.

Thiobarbituric acid value (TBA): was determined according to (Tarladgis et al ., 1960) was expressed as $\mathrm{mg}$ malonaldhyde $/ \mathrm{kg}$ fat using the following equation- TBA=7.8 $\times$ O.D. while O.D $=$ optical density at $537 \mathrm{~nm}$.

\section{Scavenging effect of DPPH:}

DPPH radical was determined by the method reported earlier by some authors (Mau et al ., 2004 ) with minor modifications. The essential oil $5,10,15,20$ and $25 \mu 1$. The mixture was shaken vigorously and left to stand for $30 \mathrm{~min}$ in dark at $30^{\circ} \mathrm{C}$, and the absorbance was then measured at $517 \mathrm{~nm}$. Using Spekol 11, Carl Zeiss Jena, German.

The percent of DPPH discoloration of the samples was calculated according to the equation .

\section{Antiradical Activity\% =}

(Absorbance of control - Absorbance of sample / Absorbance of control) x 100

\section{Extraction of volatile oils:}

The dried herbs were individually ground by domestic grinder type Moulinex and then pass through 80 mesh sieve, then each herb was extracted using hydro- distilled method for $5 \mathrm{hrs}$ in a Clevenger type apparatus. The oils were dried over anhydrous sodium sulphate and stored in dark bottle for further analysis ( Skandamis et al ., 2001).

\section{Identification of essential oils compounds by GC-MASS :}

The volatile oils were identified and determined according to (Adms, 2001 ) using GC-MASS HP $60908 \mathrm{~N}$, Mass selective xl inert detector 5975 [The oil was analyzed by GC/MS using a Agilent 5973 mass selective detector coupled to a Agilent 6890 Series II gas chromatograph, equipped with a cross-linked 5\% PH-ME siloxane HP5-MS capillary 
column $(30 \mathrm{~m} \times 0.25 \mathrm{~mm}$, film thickness of $0.25 \mu \mathrm{m})$. Operating conditions were as follows- carrier gas, helium with a flow rate of $1 \mathrm{ml} / \mathrm{min}$; column temperature, $60^{\circ} \mathrm{C}$ hold $2^{\circ} \mathrm{C}$ then increased from 60 to $250{ }^{\circ} \mathrm{C}$ for $5{ }^{\circ} \mathrm{C} / \mathrm{min}$; injector and detector temperatures, $280^{\circ} \mathrm{C}$ ]; Identification of components in the oil were based on computer matching with the Wiley7Nist05.L and NIST05.L library. At Food Technology research institute - Giza- Egypt

Total Bacterial Count (TBC): samples of $1 \mathrm{~g}$. from each plate were aseptically weight after mixing thoroughly with sterile spatula and blended with $40 \mathrm{ml}$ sterile water for min. and incubating at $37^{\circ} \mathrm{C}$ for 48 hours and expressed cfu according to the method described by (APHA 2001)

Sensory Evaluation : meat samples were evaluated according to the method described by ( Cross et al ., 1987 ) at Food industries Dept. Fac. of Agriculture and Home Economics Dept. , Fac. of Specific Education, Mansoura Univ. , Egypt.

Statistical analysis: Values represented are the means and standard error, significance was used at $p . \leq 0.01$, (ANOVA) was done using (SPSS 2007) program for windows.

\section{RESULTS AND DISCUSSIONS}

\section{Separation and identification of volatile compounds in herbs and spices}

Volatile oils from natural herbs were identified and determined using GC-Mass analysis. Data displayed in Table (1) revealed that these different essential oils under investigation contained different essential compounds namely, volatiles compounds phenolics, terpenes, oxygenated compounds.

Ginger oil are considered as a source of natural antioxidants, become most ginger rhizome and their oils used for spices in different tropical areas, the rhizome of popular ginger species is well known to have potent antioxidants (Waskmundzka et al ., 2007, Zeyada et al., 2007 and Zheng and Wang 2001). Chemical composition of ginger oil (Gingibren officinale), were identified and tabulated in Table (1) about fifty compounds were fractionated a great chemical homogeneity characterized by high amount of zingiberene $(28.99 \%$ ) which was the major essential compounds, followed by geranial $(4.53 \%)$, curcumene $(5.03 \%)$, other compounds namely oxygenated monoterpens like cineol $(2.1 \%)$, mono hydrocarbons were camphor+camphene $9.77 \%$, sabeine $3.04 \%$ and other 
sequesterpens hydrocarbons presented $\beta$ - sesuiphellandrene and $\beta-$ Bisabolene were 2.9 and $1.7 \%$.These data are in accordance with those obtained by (Sasidharan and Nirmala, 2010 )

Clove oil is not only use as natural source of food flavoring, but also have a medicinal properties for the treatment of various diseases . The chemical constitutes of commercial clove oil (Eugenia caryophyllata) and its main compounds was tested also, among them Eugenol (66.22\%) further more some interesting compounds were identified namely $\beta$ - Caryophyllene and cymene, Eugenol acetate were detected (7.89\%) ( Kim et al., 1994 and Adms , 2001 )

Peppermint oil (Mentha piperita.) used as natural antioxidants in food flavoring as herbs was identified by GC-Mass nearly 45 compounds were identified, over $50 \%$ of the total volatile compounds from menthol $(45.21 \%)$ the major volatile fraction responsible for the aromatic and sharp flavour,

Also, It is interesting to note that the peppermint oil consisted of monoterpenes, terpenoic alcholos, ketones and esters the essential compounds in peppermint characterized the main aroma compounds were menthone $(22.0 \%)$, Isomenthone $(5.43 \%)$ ), menthyl acetate $(2.4 \%))$. These compounds may be formed during the preparation of plant .( Orav and Kann , 2001 ) 
Effect of Addition OF volatile Oils from Clove, Ginger and Peppermint

Table (1) Some major components in volatile oils extracted from ginger , clove and peppermint .

\begin{tabular}{|c|c|c|}
\hline Volatile oils & Identified constituents & Area \% \\
\hline \multirow{7}{*}{ 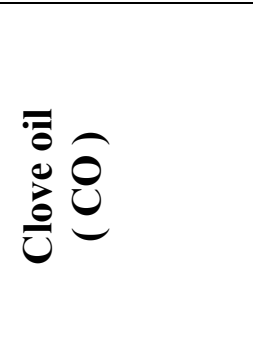 } & Eugenol & 66.22 \\
\hline & Eugenyl acetate & 7.89 \\
\hline & $\beta$ - caryophyllene & 3.32 \\
\hline & Linalool & 2.01 \\
\hline & $\beta$-Ocimene & 0.61 \\
\hline & $\alpha$-Pinene & 0.3 \\
\hline & Cymene & 0.03 \\
\hline \multirow{13}{*}{ 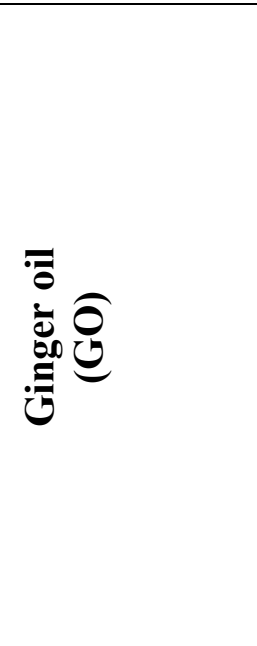 } & Zinghbrene & 28.99 \\
\hline & Camphor+ camphene & 9.77 \\
\hline & Curcumene & 5.03 \\
\hline & Geranial & 4.53 \\
\hline & Sabinene & 3.04 \\
\hline & $\beta$-sesuiphellandrene & 2.9 \\
\hline & Cineole & 2.1 \\
\hline & Nerolidol & 1.8 \\
\hline & Limonene & 1.7 \\
\hline & $\beta$-Bisabolene & 1.70 \\
\hline & Borneol & 1.62 \\
\hline & $\alpha$ - terpenol & 1.1 \\
\hline & Cayrophyllene & -- \\
\hline \multirow{8}{*}{ 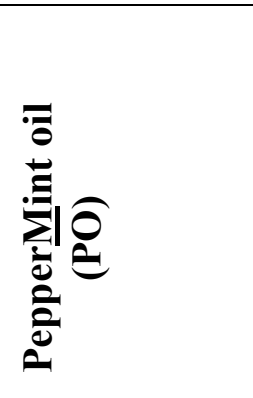 } & Menthol & 45.21 \\
\hline & Menthone & 22.00 \\
\hline & Isomenthone & 5.43 \\
\hline & Menthyl acetate & 2.4 \\
\hline & $\beta$ - caryophyllene & 2.32 \\
\hline & Cineole & 0.5 \\
\hline & Carvone & 0.32 \\
\hline & Linalool & 0.31 \\
\hline
\end{tabular}

Radical Scavenging activity of herbs and spices oils-

Radical scavenging assay were evaluated by DPPH technique which depend on donate hydrogen to free radical and inhibiting the propagation stage in lipids oxidation pathway (Niki, 1991 ) 
The radical scavenging activity of natural volatile oils depends greatly on the concentration as resulted in Table (2). All volatile oils under investigation exhibited high DPPH results in compare with synthetic one TBHQ, while, The highest scavenging activity was detected at the concentration of $25 \mu 1$ from clove oil , which reached to $89.91 \%$, followed by ginger oil and peppermint oil which were 88.87 and $87.87 \%$ respectively at the same concentrate.

These obtained results indicate that natural oils from herbs and spices oils under investigation have a noticeable effect on scavenging free radicals.

These are also attribute to their molecular structure and their content of phenolics and aromatic compounds namely eugenol, carvone, menthol and zingabrene act as free radical scavenging and have the ability to chelating transition metals means inactivation of iron ions. ( Martin et al ., 2002 ). The antiradical scavenging activity would be related to the substitution of hydroxyl groups in the aromatic rings of phenolics, thus contributing to their hydrogen donating ability. And their content of phenolics compounds and hydroxyl groups contribute markedly to the antioxidant activity (Wojdylo et al ., 2007).

Table (2) Free radical of scavenging activity DPPH on volatile oils used in minced meat preservation .

\begin{tabular}{|l|c|c|c|c|c|}
\hline \multirow{2}{*}{ Volatile oils } & \multicolumn{5}{|c|}{ Volatile oils concentrate } \\
\cline { 2 - 6 } & $5 \mu 1$ & $10 \mu 1$ & $15 \mu 1$ & $20 \mu 1$ & $25 \mu 1$ \\
\hline TBHQ & $88.26 \%$ & $94.72 \%$ & $95.07 \%$ & $96.71 \%$ & $98.11 \%$ \\
\hline Clove oil ( CO ) & $85.72 \%$ & $87.90 \%$ & $88.11 \%$ & $88.78 \%$ & $89.91 \%$ \\
\hline Ginger (GO) & $84.98 \%$ & $85.11 \%$ & $86.11 \%$ & $87.31 \%$ & $88.87 \%$ \\
\hline Peppermint oil (PO) & $75.24 \%$ & $77.22 \%$ & $79.55 \%$ & $85.55 \%$ & $87.87 \%$ \\
\hline
\end{tabular}

\section{Chemical composition of fresh minced beef meat -}

Data in Table (3) showed the gross chemical composition of fresh minced meat, Moisture content was $65.61 \pm 0.31$, Protein content was $18.62 \pm 0.51$,Crude fat and Ash were 13.65 and 2.11 respectively and TVB$\mathrm{N}$ were $5.04 \mathrm{mg} \backslash 100 \mathrm{gm}$ sample. These results are in accordance with those given by Salem et al ., $\mathbf{2 0 1 0}$ and different from obtained with Solomakas et al ., (2008) who found that chemical composition of minced meat were $72.27,21.8$ and $2.47 \%$ for moisture ,protein and ash respectively. 
Our obtained results indicated that raw material used in this research contained a high amount of fat which could be attributed the changes in meat quality during cold storage .

Table (3) Gross chemical composition of fresh minced beef meat.

\begin{tabular}{|l|c|c|c|c|c|}
\hline \multirow{2}{*}{$\begin{array}{l}\text { Chemical } \\
\text { constitutes }\end{array}$} & \multicolumn{5}{|c|}{ Minced beef meat } \\
\cline { 2 - 6 } & Moisture & Ash & Protein & TVB-N & Crude FAT \\
\cline { 2 - 6 } & $65.61 \pm 0.31$ & $2.11 \pm 0.02$ & $18.62 \pm 0.51$ & $5.04 \pm 0.01$ & $13.65 \pm 0.20$ \\
\hline
\end{tabular}

Each value is the mean of three replicates $\pm \mathrm{SD}$

\section{2- Changes in minced meat properties during cold storage at 3-5 $\mathrm{C}$ for} 10 days .-

1-Changes in physical properties

\section{A)Changes in colour -}

The colour of meat can changed during cold storage, according to the status of the myoglobin, which may change from the purplish red of deoxygenated Myoglobien to the bright red of Oxymyoglobin or brown/grey of Metmyoglobin., When MMb reaches approximately 30 to $40 \%$ of the total chemical states of Myoglobien, a brown color becomes visible ( Lee et al ., 1998). (Table 4 )

Table (4 ) Changes in Metamyglobien (MMB)\% in treated minced meat during cold storage at $3-5^{\circ} \mathrm{C}$ for 10 days .

\begin{tabular}{|c|c|c|c|c|c|c|}
\hline $\begin{array}{r}\begin{array}{r}\text { Storage periods } \\
\text { per days }\end{array} \\
\text { Treatments }\end{array}$ & Zero & 2 days & 4 days & 6 days & 8 days & 10 days \\
\hline Control & $26.63 \pm 0.12$ & $42.62 \pm 0.13$ & $50.62 \pm 0.07$ & $58.98 \pm 0.03$ & $76.31 \pm 0.04$ & $88.90 \pm 0.20$ \\
\hline Clove oil ( CO ) & $26.63 \pm 0.01$ & $32.92 \pm 0.03 * *$ & $35.16 \pm 0.05 * *$ & $40.76 \pm 0.02 * *$ & $43.08 \pm 0.01 * *$ & $45.32 \pm 0.03 * *$ \\
\hline Ginger oil (GO) & $26.63 \pm 0.03$ & $32.92 \pm 0.02 * *$ & $35.63 \pm 0.01 * *$ & $40.78 \pm 0.05^{* *}$ & $44.09 \pm 0 / 01 * *$ & $46.56 \pm 0.03 * *$ \\
\hline $\begin{array}{c}\text { Peppermint oil } \\
\text { (PO) }\end{array}$ & 26. $63 \pm 0.04$ & $32.90 \pm 0.05^{* *}$ & $35.93 \pm 0.03 * *$ & $40.87 \pm 0.02 * *$ & $45.07 \pm 0.02 * *$ & $47.99 \pm 0.02 * *$ \\
\hline $\begin{array}{l}\text { Clove oil + } \\
\text { ginger oil }\end{array}$ & $26.63 \pm 0.02$ & $32.90 \pm 0.02 * *$ & $34.89 \pm 0.02 * *$ & $38.9 \pm 0.02 * *$ & $42.44 \pm 0.03 * *$ & $45.08 \pm 0.01 * *$ \\
\hline $\begin{array}{l}\text { Clove oil + } \\
\text { peppermint oil }\end{array}$ & 26. $63 \pm 0.01$ & $34.99 \pm 0.01 * *$ & $34.90 \pm 0.03 * *$ & $39.98 \pm 0.03 * *$ & $41.89 \pm 0.02 * *$ & $43.93 \pm 0.01 * *$ \\
\hline $\begin{array}{l}\text { Clove oil + } \\
\text { peppermint oil } \\
+ \text { ginger oil } \\
\end{array}$ & 26. $63 \pm 0.01$ & $31.70 \pm 0.04 * *$ & $34.63 \pm 0.04 * *$ & $36.91 \pm 0.02 * *$ & $38.55 \pm 0.03 * *$ & $41.73 \pm 0.01 * *$ \\
\hline
\end{tabular}

Each value is the mean of three replicates $\pm \mathrm{SD}$

** Means with a Colum are Significantly different with control ( $\mathrm{p} .<0.01$ ) 
Data presented in Table (4) illustrated that there were significant differences significantly observed in minced meat treated with different volatile oils at the concentration of $1 \%$ in compare with control meat sample.

Results of colour showed that colour of control meat samples was increased prolonged storage period from 26.36 to $88.90 \%$. while the changes in MMB \% were decreased with the addition of different volatile oils at the concentrate of $1 \%$. The lowest changes in Metamyglobien were detected in minced meat treated with clove oil + peppermint oil + ginger oil $(1 \%)$ which were 26.63 to $41.73 \%$, The results also indicated that the changes in $\mathrm{MMb}$ were nearly the same in treated meat samples with the mixture of clove oil with both of ginger oil and peppermint oil .

Treated minced meat with essential oils which contained volatile compounds have a synergistic effect in reducing the formation of free radical , retarded lipid oxidation, increased meat colour stability and inhibition Metamyglobien formation up to 6 days during cold storage at 3-5 ${ }^{\circ} \mathrm{C}$. These results are in accordance with( Juliani, and Simon 2002 , Salih, 2009 ) who stated that addition of Christi extracts and Tocopherol suppressed lipid oxidation in cold beef steak up to 9 days of storage .

\section{Changes in $\mathbf{p H}$ values :}

Results in Table ( 5 ) indicated that, $\mathrm{pH}$ values were increased from 5.70 to 7.9 in control beef samples during cold storage . During the first 2 days of cold storage the changes in $\mathrm{pH}$ values increased within narrow limit from 6.0 to 6.2 in all treated minced meat, then $\mathrm{pH}$ increased rapidly to 6.8 at the end of storage period in minced meat treated with peppermint oil $1 \%$ at 10 days of storage. Although at 8 to 10 days of storage the degree of alkalinity was observed in all cold stored minced meat samples.

Results also indicated that $\mathrm{pH}$ values in all meat samples treated with different volatile oils were slightly increased,the lowest changes were observed in treated meat samples with clove oil + peppermint oil + ginger oil ( $1 \%$ ) which extended the self life up to 8 days, ( value of $\mathrm{pH}$ was 6.33 ).

Meat samples treated with clove oil + ginger oil and clove oil + peppermint oil at the concentrate of $1 \%$ showed a moderate effect in lowering the values of $\mathrm{pH}$, and these extract could extend the self -life up to 6 days. 
The increase of $\mathrm{pH}$ found to be high value after 6 days of storage at $3-5^{\circ} \mathrm{C}$ in meat samples treated with the individual volatile oils namely clove, ginger and peppermint oil at the concentrate of $1 \%$ : Increase of $\mathrm{pH}$ values due to basic metabolites produced by bacteria predominally gram ${ }^{+}$and psyscrophillic from metabolism of protein (Bell and Shelef ,1987 and Agunbide et al ., 2010 ) .

Table (5) Changes in $\mathrm{pH}$ in treated minced meat during cold storage at $3-5^{\circ} \mathrm{C}$ for 10 days .

\begin{tabular}{|l|c|c|c|c|c|c|}
\hline Treatments & Zero & 2 days & 4 days & 6 days & 8 days & 10 days \\
\hline Control & 5.70 & 6.11 & 6.80 & 6.90 & 7.51 & 7.90 \\
\hline Clove oil ( CO) & 5.70 & 6.15 & 6.28 & 6.70 & 6.77 & 6.90 \\
\hline Ginger oil (GO) & 5.70 & 6.17 & 6.33 & 6.60 & 6.73 & 6.99 \\
\hline Peppermint oil (PO) & 5.70 & 6.20 & 6.33 & 6.70 & 6.76 & 6.88 \\
\hline Clove oil + ginger oil & $\mathbf{5 . 7 0}$ & $\mathbf{6 . 0 9}$ & $\mathbf{6 . 1 4}$ & $\mathbf{6 . 3 0}$ & $\mathbf{6 . 3 4}$ & $\mathbf{6 . 7 1}$ \\
\hline Clove oil + peppermint oil & 5.70 & 6.11 & 6.80 & 6.66 & 6.73 & 6.72 \\
\hline $\begin{array}{c}\text { Clove oil + peppermint oil } \\
\text { + ginger oil }\end{array}$ & 5.70 & 6.15 & 6.28 & 6.26 & 6.33 & 6.70 \\
\hline
\end{tabular}

\section{1-Chanes in chemical properties}

a) Changes in Total Volatile Basis Nitrogen (TVB-N )

Values of TVB-N are summarized inTable ( 6 ) estimating the degree of decomposition and deterioration which caused by microorganisms as well as protein breakdown caused by tissue proteolytic enzymes during the storage period ( Pearson, 1986).

TVB-N was determined at several intervals time during cold storage. Table (6) showed that all treated minced meat had nearly the same TVB-N content at zero time and up to 2 days of storage were 5.70 to $12.61 \mathrm{mg}$ TVN/ 100 g. sample, furthermore TVB-N were progressively increased in control samples during cold storage period and the values of TVB-N increased from 5.70 to $35.60 \mathrm{mg}$ TVN/ $100 \mathrm{~g}$ sample from zero time up to 10 days of storage respectively ..

While the lowest values in TVB-N were detected in treated meat samples with clove + ginger + peppermint oil at the concentration of $1 \%$, also, the changes in TVB-N could be arranged ascendingly in the other treated minced meat samples as follow clove + ginger oils $<$ Clove oil + 
peppermint oil $<$ Clove oil $<$ ginger oil $<$ peppermint oil prolonged storage period. (Table 6).

So, Treated minced meat with mixture of ginger + clove + peppermint oils at the concentration of $1 \%$ was more effective in delaying the rate of TVB-N, this may be due to the role of different active compounds on the formation of alkyl groups from the protein hydrolysis which reducing bacterial growth and the reproduction microbial culture, and reduced the break down of nitrogenous substances by microbial activity. (Agunbide et al., 2010 Salem et al ., 2010)

Finally, addition of essential oils from natural herbs could reduced of the amount and forming of ammonia up to 6 days of cold of $3-5^{\circ} \mathrm{C}$.

Our data are in accordance with the acceptable limit of fresh meat being $13 \mathrm{mg} \backslash 100 \mathrm{gm}$ samples and not exceed $20 \mathrm{mg} / 100 \mathrm{gm}$ samples. So, our results showed that treated minced meat with volatile oils were acceptable for human consumption up to 8 days at $3-5^{\circ} \mathrm{C}$.

Table (6) Changes in Total Volatile Basis Nitrogen TVB-N in treated minced meat during cold storage at $3-5^{\circ} \mathrm{C}$ for 10 days .

\begin{tabular}{|c|c|c|c|c|c|c|}
\hline $\begin{array}{l}\text { Storage periods per days } \\
\text { Treatments }\end{array}$ & Zero & 2days & 4 days & 6 days & 8 days & $\begin{array}{c}10 \\
\text { days }\end{array}$ \\
\hline Control & 5.70 & 15.75 & 20.77 & 24.45 & 30.76 & 35.60 \\
\hline Clove oil ( CO ) & 5.70 & 12.61 & 14.54 & 15.52 & 18.10 & 20.51 \\
\hline Ginger oil (GO) & 5.70 & 12.46 & 16.76 & 17.62 & 19.82 & 21.66 \\
\hline Peppermint oil (po) & 5.70 & 12.61 & 17.41 & 19.72 & 21.80 & 22.65 \\
\hline Clove oil + ginger oil & 5.70 & 12.51 & 15.21 & 19.91 & 23.84 & 23.84 \\
\hline Clove oil + peppermint oil & 5.69 & 12.52 & 18.91 & 20.51 & 22.62 & 22.62 \\
\hline $\begin{array}{l}\text { Clove oil + peppermint oil } \\
+ \text { ginger oil }\end{array}$ & 5.68 & 12.61 & 14.84 & 16.61 & 18.20 & 20.51 \\
\hline
\end{tabular}

\section{2- Changes in Thiobarbituric Acid Value (TBA)}

Thiobarbituric Acid Value (TBA) . is an index for determination the degree of lipid oxidation and the formation of secondary oxidation products, namely carbonyl compounds groups aldhydes and ketones . 
Effect of Addition OF volatile Oils from Clove, Ginger and Peppermint

Table (7) Changes in Thiobarbituric acid value (TBA) mg malonaldhyde $/ \mathrm{kg}$.fat in treated minced meat during cold storage at $3-5^{\circ} \mathrm{C}$ for 10 days.

\begin{tabular}{|c|c|c|c|c|c|c|}
\hline $\begin{array}{l}\text { Storage periods per days } \\
\text { Treatments }\end{array}$ & Zero & 2days & 4 days & 6 days & 8 days & 10 days \\
\hline Control & $0.321 \pm 0.01$ & $1.852 \pm 0.01$ & $3.752 \pm 0.01$ & $4.660 \pm 0.03$ & $5.711 \pm 0.01$ & $7.731 \pm 0.01$ \\
\hline Clove oil ( CO ) & $0.321 \pm 0.01$ & $\begin{array}{c}\mathbf{0 . 9 2 3} \\
* * \pm 0.020 \\
\end{array}$ & $1.540 * * \pm 0.01$ & $1.976^{* * \pm 0.01}$ & $2.475^{* * *} \pm 0.02$ & $2.971 * * \pm 0.01$ \\
\hline Ginger oil (GO) & $0.321 \pm 0.01$ & $0.970 * * 0.04$ & $1.842^{* * \pm 0.03}$ & $2.125 * * \pm 0.06$ & $2.372 * * \pm 0.05$ & $3.971 * * \pm 0.01$ \\
\hline Peppermint oil (PO) & $0.321 \pm 0.01$ & $0.920 * * \pm 0.02$ & $1.457^{* * \pm 0.03}$ & $1.842 * * \pm 0.05$ & $2.925 * * \pm 0.02$ & $3.177 * * \pm 0.03$ \\
\hline Clove oil + ginger oil & $0.321 \pm 0.01$ & $0.790 * * \pm 0.01$ & $1.317 * * \pm 0.03$ & $1.495^{* * \pm 0.01}$ & $2.711 * * \pm 0.01$ & $2.879 * * \pm 0.04$ \\
\hline Clove oil + peppermint oil & $0.321 \pm 0.01$ & $.582 * * \pm 0.03$ & $0.942 * * \pm 0.03$ & $1.492 * * \pm 0.04$ & $2.475 * * \pm 0.02$ & $2.970 * * \pm 0.02$ \\
\hline $\begin{array}{l}\text { Clove oil + peppermint oil } \\
+ \text { ginger oil }\end{array}$ & $0.321 \pm 0.01$ & $.430 * * \pm 0.01$ & $0.539 \pm 0.01$ & $1.481 * * \pm 0.03$ & $1.972 * * \pm 0.05$ & $2.731 * * \pm 0.01$ \\
\hline
\end{tabular}

Each value is the mean of three replicates $\pm \mathrm{SD}$

** Means with a Colum are Significantly different with control (p. $\leq 0.01)$

Data in Table( 7 ) showed that the TBA values were found to be significantly higher content in control samples in compare with other treated minced meat with volatile oils, TBA values were also, when storage period at $3-5^{\circ} \mathrm{C}$ increased for 10 days, the values were increased from 0.321 to $7.731 \mathrm{mg}$ malonaldhyde/ $\mathrm{kg}$ fat .

The increment in TBA values due to formation of carbonyl compounds products during the oxidation process of lipids. However, addition of volatile oils at the concentration of $1 \%$ to minced meat in decreasing the TBA values during cold storage. This could be attributed that mixture of volatile oils which contained different aromatic compounds may be retarding the oxidation process and quenching the free radicals in lipids then extend the shelf life of minced meat (Raharjo and Sofos ,1993)

The lowest significant increment of TBA values was observed in minced meat sample treated with the mixture of clove + ginger + peppermint oil $1 \%$, followed with the samples treated with the combination of clove + ginger oil and clove + peppermint oil 1\% (2.731 and 2.879) mg malonaldhyde $/ \mathrm{kg}$ fat respectively .

The increase in TBA values was slightly observed in all treated minced meat beef during cold storage, this could be due to the auto- 
oxidation of meat lipids, bacteriological and/or oxidative rancidity (Ali , 2010 ).

Our obtained results were in the acceptable limit 0.5 to $2.0 \mathrm{mg}$ malonaldhyde $/ \mathrm{kg}$ fat in all treated minced beef up to 6 days of storage at 3$5^{\circ} \mathrm{C}$. (Raharjo and Sofos 1993 )

So, it could be concluded that the addition of mixture of volatile oils from Clove oil + peppermint oil + ginger oil resulted in lowering the TBA values and act as a high scavenger of radicals involved in lipid peroxidation and preventing minced meat from deterioration, these results are in accordance with( Ismail et al .,2009 and Salem et al ., 2010 ).

Volatile compounds are also related to inhibiting the activity of conjugated rings and hydroxyl groups (Decker, 1995). Generally, addition of $1 \%$ and natural antioxidants oils improved the stability of lipids and have special effect in preventing oxidation during cold storage.

\section{3- Changes in Total Bacterial Count (TBC)}

Total bacterial count TBC were enumerated for different minced meat samples, Results in Table (8) showed that addition of all volatile oils at the concentration of $1 \%$ have higher inhibitory effect against bacterial growth in compare with control meat samples.

Table (8) Changes in Total Bacterial Count (TBC) cfu/g. in treated minced meat during cold storage at $3-5^{\circ} \mathrm{C}$ for 10 days

\begin{tabular}{|l|c|c|c|c|c|c|}
\hline $\begin{array}{r}\text { storage periods per } \\
\text { days }\end{array}$ & Zero & 2 days & 4 days & 6 days & 8 days & 10 days \\
\hline Treatments & $5.2 \times 10^{2}$ & $8.7 \times 10^{4}$ & $8.9 \times 10^{5}$ & $9.2 \times 10^{6}$ & $9.9 \times 10^{6}$ & $19.9 \times 10^{7}$ \\
\hline Clove oil ( CO) & $5.4 \times 10^{2}$ & $8.9 \times 10^{3}$ & $8.1 \times 10^{4}$ & $6.6 \times 10^{5}$ & $8.3 \times 10^{5}$ & $6.9 \times 10^{6}$ \\
\hline Ginger oil (GO) & $5.6 \times 10^{2}$ & $8.7 \times 10^{3}$ & $7.9 \times 10^{4}$ & $6.5 \times 10^{5}$ & $6.4 \times 10^{5}$ & $8.5 \times 10^{6}$ \\
\hline Peppermint oil (PO) & $5.5 \times 10^{2}$ & $6.5 \times 10^{4}$ & $7.7 \times 10^{5}$ & $6.9 \times 10^{5}$ & $5.1 \times 10^{5}$ & $6.3 \times 10^{6}$ \\
\hline Clove oil + ginger oil & $5.3 \times 10^{2}$ & $7.9 \times 10^{3}$ & $7.1 \times 10^{4}$ & $6.9 \times 10^{5}$ & $3.8 \times 10^{5}$ & $6.2 \times 10^{6}$ \\
\hline Clove oil + peppermint oil & $5.4 \times 10^{2}$ & $7.6 \times 10^{3}$ & $7.1 \times 10^{4}$ & $6.7 \times 10^{5}$ & $7.6 \times 10^{5}$ & $5.9 \times 10^{6}$ \\
\hline $\begin{array}{l}\text { Clove oil + peppermint oil } \\
+ \text { +ginger oil }\end{array}$ & $5.3 \times 10^{2}$ & $6.2 \times 10^{3}$ & $6.3 \times 10^{4}$ & $6.6 \times 10^{5}$ & $6.8 \times 10^{5}$ & $6.9 \times 10^{5}$ \\
\hline
\end{tabular}


Total Bacterial Count (TBC) of refrigerated minced beef incorporated with $1 \%$ volatile oils from clove, ginger and peppermint and the mixture of them were evaluated during cold storage at $3-5^{\circ} \mathrm{C}$ for 10 days ,.Results are shown in Table $(8)$, revealed that all treated minced meat exhibited similar TBC at zero time of storage which ranged from $5.2 \times 10^{2}$ to $5.6 \times 10^{2} \mathrm{cfu} / \mathrm{g}$. . There were a slight increase in Total Bacterial Count TBC in all treated minced meat samples, increases in TBC which observed in control samples were higher than the other treated minced beef samples . The increment was ranged from $5.2 \times 10^{2}$ to $19.9 \times 10^{7}$ at zero time and 10 days of storage period at $3-5^{\circ} \mathrm{C}$

While, all treated minced meat with different volatile oils showed slight increase in TBC up to 8 days of storage, the lowest TBC was detected in minced treated with the mixture of clove, ginger and peppermint oils with the level of $1 \%$ resulted in population of TBC were lower than the control sample during storage at $3-5^{\circ} \mathrm{C}$ for 6 days. and exhibited the lowest means counts of bacteria comparing with others treatments .

It consider to note that addition of volatile oils which contained a variety of aromatic compounds, namely eugenol, menthol, terpens and zingebrene could be act as antibacterial agents and also, were more effective in extending the self life of minced beef meat during cold storage . These results are in agreed with those obtained by Skandamis and Nychas, (2001) who reported that bacteria of the genera Listeria, Bacillus, Clostridium and Staphylococcus were sensitive to volatile compounds namely alcohols, phenols, esters which considered as the main components in herbs and spices ,also, Theses results are in agreement with those reported by Oke et al ., (2009) who stated that herb and spice extracts and their volatile oils contained natural sources of antimicrobial mixtures or a purified compounds are inhibited the bacterial growth which extended the storage period of processed foods .

\section{4- Sensory evaluation of minced beef meat treated with different volatile oils during cold storage at $3-5^{\circ} \mathrm{C}$ for 10 days.}

Data in Table ( 9 ), showed that colour score decreased significantly $\mathrm{P}<0.01$ with the increasing of storage period, the score of colour could be arranged ascendingly in treated meat with different volatile oil as follows: clove oil + peppermint oil + ginger oil $<$ clove oil + ginger oil $<$ clove oil + peppermint oil $<$ clove oil $<$ ginger oil $<$ peppermint oil. Almost no detectable changes observed in colour after 2days of storage in all treated 
meat samples, while the changes were observed slightly in treated with peppermint oil and ginger oil .

Table (9) Changes in sensory properties in treated minced meat during cold storage at $3-5^{\circ} \mathrm{C}$ for 10 days

\begin{tabular}{|c|c|c|c|c|c|}
\hline treatments & $\begin{array}{c}\text { Storage } \\
\text { period }\end{array}$ & colour & odour & Juiciness & $\begin{array}{c}\text { Overall } \\
\text { acceptability }\end{array}$ \\
\hline \multirow{6}{*}{ 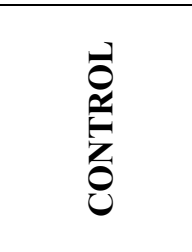 } & 0 & $8.50 \pm 0.04$ & $8.50 \pm 0.02$ & $8.77 \pm 0.02$ & $8.65 \pm 0.05$ \\
\hline & 2 & $7.05 \pm 0.03$ & $7.14 \pm 0.01$ & $7.55 \pm 0.01$ & $6.85 \pm 0.01$ \\
\hline & 4 & $6.22 \pm 0.04$ & $6.45 \pm 0.01$ & $6.80 \pm 0.02$ & $5.42 \pm 0.05$ \\
\hline & 6 & $5.14 \pm 0.05$ & $6.29 \pm 0.01$ & $6.30 \pm 0.03$ & $5.28 \pm 0.03$ \\
\hline & 8 & $5.01 \pm 0.06$ & $5.11 \pm 0.04$ & $6.22 \pm 0.03$ & $4.57 \pm 0.03$ \\
\hline & 10 & $4.88 \pm 0.01$ & $5.09 \pm 0.03$ & $5.98 \pm 0.05$ & $3.14 \pm 0.01$ \\
\hline \multirow{6}{*}{$\begin{array}{l}\bar{\theta} \\
0 \\
\overline{0} \\
\overline{0}\end{array}$} & 0 & $8.50 \pm 0.04$ & $8.50 \pm 0.02$ & $8.77 \pm 0.02$ & $8.65 \pm 0.05$ \\
\hline & 2 & $8.20^{* * * *} \pm 0.01$ & $8.15^{2 \pi *} \pm 0.01$ & $8.15^{* * \pi} \pm 0.02$ & $8.50^{* *} \pm 0.02$ \\
\hline & 4 & $8.10^{* * *} \pm 0.02$ & $8.10^{* * *} \pm 0.03$ & $8.72^{* *} \pm 0.03$ & $8.49^{* * *} \pm 0.04$ \\
\hline & 6 & $7.44^{k * *} \pm 0.05$ & $7.70^{* * *} \pm 0.02$ & $7.90^{* * *} \pm 0.02$ & $8.20^{* * *} \pm 0.02$ \\
\hline & 8 & $7.14^{* *} \pm 0.01$ & $7.50^{* * *} \pm 0.03$ & $7.44^{* * *} \pm 0.05$ & $7.70^{* *} \pm 0.01$ \\
\hline & 10 & $7.03^{* 3 *} \pm 0.05$ & $7.03^{2 * *} \pm 0.03$ & $7.50^{* * *} \pm 0.02$ & $7.50^{* *} \pm 0.02$ \\
\hline \multirow{6}{*}{$\begin{array}{l}\bar{\theta} \\
\overline{\bar{\theta}} \\
\dot{8} \\
\dot{0}\end{array}$} & 0 & $8.50 \pm 0.04$ & $8.50 \pm 0.02$ & $8.77 \pm 0.02$ & $8.65 \pm 0.05$ \\
\hline & 2 & $8.06^{* \pi *} \pm 0.01$ & $8.15^{* \pi *} \pm 0.01$ & $8.50^{k \times 2} \pm 0.03$ & $8.50^{* *} \pm 0.02$ \\
\hline & 4 & $7.90^{k * *} \pm 0.03$ & $8.07^{* \pi *} \pm 0.03$ & $7.88^{* \pi /} \pm 0.01$ & $7.85^{* \pi *} \pm 0.04$ \\
\hline & 6 & $7.30^{* * *} \pm 0.02$ & $7.60^{* * *} \pm 0.02$ & $7.45^{* * \pi} \pm 0.03$ & $7.70^{* *} \pm 0.01$ \\
\hline & 8 & $711^{* * k} \pm 0.03$ & $7.20^{* *} \pm 0.03$ & $7.10^{*^{*}} \pm 0.02$ & $7.50^{* *} \pm 0.02$ \\
\hline & 10 & $7.09^{x * * *} \pm 0.04$ & $7.00^{* * x} \pm 0.01$ & $7.00^{* \pi *} \pm 0.02$ & $7.30^{* *} \pm 0.03$ \\
\hline \multirow{6}{*}{ 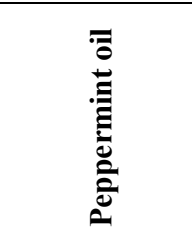 } & 0 & $8.50 \pm 0.04$ & $8.50 \pm 0.02$ & $8.60 \pm 0.03$ & $8.65 \pm 0.05$ \\
\hline & 2 & $8.20^{* * k} \pm 0.01$ & $8.15^{* * *} \pm 0.01$ & $8.15^{* * x} \pm 0.02$ & $8.50^{* *} \pm 0.02$ \\
\hline & 4 & $8.10^{* * *} \pm 0.02$ & $8.00^{* \pi *} \pm 0.01$ & $7.90^{\pi * \pi} \pm 0.01$ & $8.30^{* \pi *} \pm 0.03$ \\
\hline & 6 & $7.97^{k * *} \pm 0.04$ & $7.50^{* * *} \pm 0.03$ & $7.58^{* k} \pm 0.02$ & $7.66^{* * *} \pm 0.04$ \\
\hline & 8 & $7.44^{* * *} \pm 0.05$ & $7.14 \pm 0.03^{* \pi k}$ & $7.43^{k * x} \pm 0.02$ & $7.30^{* * * x} \pm 0.04$ \\
\hline & 10 & $7.20^{* * *} \pm 0.03$ & $6.10^{* * *} \pm 0.01$ & $7.05^{* *} \pm 0.02$ & $7.21^{* \pi / 2} \pm 0.04$ \\
\hline \multirow{6}{*}{ 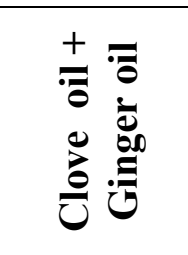 } & 0 & $8.50 \pm 0.04$ & $8.50^{* * *} \pm 0.02$ & $8.77 \pm 0.02$ & $8.65 \pm 0.05$ \\
\hline & 2 & $8.44^{2 k *} \pm 0.01$ & $8.15^{* * k} \pm 0.01$ & $8.15^{* * *} \pm 0.02$ & $8.50^{* *} \pm 0.02$ \\
\hline & 4 & $8.12^{* * *} \pm 0.02$ & $8.10^{* * *} \pm 0.03$ & $7.80^{* * \pi} \pm 0.02$ & $8.49^{* \pi * x} \pm 0.03$ \\
\hline & 6 & $7.56^{* * *} \pm 0.03$ & $7.98^{* * *} \pm 0.05$ & $7.65^{* *} \pm 0.02$ & $8.20^{* * *} \pm 0.02$ \\
\hline & 8 & $7.23^{k \pi *} \pm 0.01$ & $7.70^{* \pi *} \pm 0.02$ & $7.55^{* \pi} \pm 0.02$ & $7.66^{* * *} \pm 0.04$ \\
\hline & 10 & $7.14^{* * * x} \pm 0.02$ & $7.03^{* * x} \pm 0.03$ & $7.44^{* * \pi} \pm 0.02$ & $7.54^{* * \pi} \pm 0.03$ \\
\hline \multirow{6}{*}{ 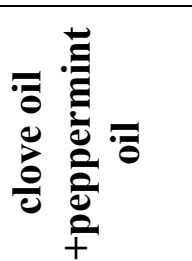 } & 0 & $8.50 \pm 0.04$ & $8.50 \pm 0.02$ & $8.77 \pm 0.02$ & $8.65 \pm 0.05$ \\
\hline & 2 & $8.43^{* *} \pm 0.01$ & $8.20 \pm 0.01$ & $8.15^{* * *} \pm 0.02$ & $8.50^{* *} \pm 0.02$ \\
\hline & 4 & $8.00^{* * *} \pm 0.01$ & $7.90^{* * *} \pm 0.03$ & $7.88^{* * \pi} \pm 0.02$ & $8.44^{\text {2*1/2}} \pm 0.02$ \\
\hline & 6 & $7,94^{* *} \pm 0.01$ & $7.67^{* * \star} \pm 0.02$ & $7.77^{* * *} \pm 0.02$ & $7.85^{* * *} \pm 0.04$ \\
\hline & 8 & $7.85^{* *} \pm 0.01$ & $7.50^{* * *} \pm 0.03$ & $7.60^{x * x} \pm 0.02$ & $7.50^{* * \pi} \pm 0.03$ \\
\hline & 10 & $7.70^{* *} \pm 0.01$ & $7.30^{* * \pi} \pm 0.01$ & $7.50^{k * \pi} \pm 0.02$ & $7.66^{* \pi *} \pm 0.03$ \\
\hline
\end{tabular}


Effect of Addition OF volatile Oils from Clove, Ginger and Peppermint

\begin{tabular}{|c|c|c|c|c|c|}
\hline treatments & $\begin{array}{l}\text { Storage } \\
\text { period }\end{array}$ & colour & odour & Juiciness & $\begin{array}{c}\text { Overall } \\
\text { acceptability }\end{array}$ \\
\hline \multirow{6}{*}{ 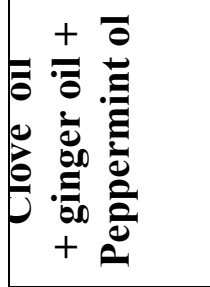 } & 0 & $8.50 \pm 0.04$ & $8.50 \pm 0.02$ & $8.77 \pm 0.02$ & $8.65 \pm 0.05$ \\
\hline & 2 & $8.40^{* * *} \pm 0.03$ & $8.20^{* * *} \pm 0.02$ & $8.20^{k * k} \pm 0.02$ & $8.63^{* * *} \pm 0.02$ \\
\hline & 4 & $8.14^{k * \pi} \pm 0.02$ & $8.10^{\pi * \pi} \pm 0.01$ & $7.90^{* * *} \pm 0.01$ & $8.50^{* \pi *} \pm 0.04$ \\
\hline & 6 & $7.91^{* * *} \pm 0.01$ & $8.02^{* * *} \pm 0.02$ & $7.80^{* * *} \pm 0.04$ & $8.30^{* * *} \pm 0.01$ \\
\hline & 8 & $7.80^{k .2} \pm 0.03$ & $7.88^{k * k} \pm 0.03$ & $7.67^{* * *} \pm 0.05$ & $7.88^{* * *} \pm 0.02$ \\
\hline & 10 & $7.69^{k *} \pm 0.02$ & $7.50^{* * *} \pm 0.04$ & $7.55^{* * k} \pm 0.01$ & $7.70^{* * *} \pm 0.03$ \\
\hline
\end{tabular}

Each value is the mean of three replicates $\pm \mathrm{SD}$

** Means with a Colum are Significantly different with control (p. $\leq 0.01)$

The changes in colour may be due to lipid oxidation and subsequent of oxidized compounds reacting amino acids causing non enzymatic browning products ( Frankel, 1998 ) and could be also attributed to the storage conditions which lead to discoloration of Myoglobien from bright red to pale colour . (Agunbide, 2010)

Data in the same table revealed that, score of odour was also, decreased at prolonged storage period, results were nearly the same after the first 4 days of storage in all treated meat samples after that, the changes were increased rapidly. An increase of unpleasant odour was observed highly in control meat samples in compare with other treatment. The best scores were evident in meat samples treated with clove oil + peppermint oil + ginger oil $1 \%$, followed with meat samples treated with ginger + clove oil .

Reduction of odour could be mainly attributed to the increases of free fatty acids and could be detected sensorial if the TBA values were more than $0.2 \mathrm{mg}$ malonaldhyde/kg fat. (Ali, 2010 ).

Similar results could be also observed in juiciness, the changes were higher in control samples in compare with other treated meat samples the changes Could be due to the refrigeration conditions which affected the retention of moisture during storage period at $3-5^{\circ} \mathrm{C}$ ( Salem et al ., 2010 and Kandeepan et al ., 2011)

Overall acceptability of all treated mined meat samples decreased also, significantly prolonged storage period .The gradual increase was detected in samples treated with Clove oil + peppermint oil + ginger oil with the concentrate of $1 \%$. So, addition of volatile oils either individual or mixtures to minced meat which contained various compounds namely 
alcohols, poly phenols, esters , oxygenated compounds and terpens enchanted the sensorial properties of meat during storage period at $3-5^{\circ} \mathrm{C}$ for 10 days .

Therefore, addition the mixture of volatile oils from natural herbs clove oil + peppermint oil + ginger oil is recommended to avoid the lipid and protein deterioration in commercial minced beef meat during cold storage at $3-5^{\circ} \mathrm{C}$ to extended the shelf life up to 8 days.

It is notable that, the effect of volatile oils as a potential antioxidants was more pronounced on reducing both of some physical and chemical changes rather than the microbiological changes of minced meat during cold storage at $3-5^{\circ} \mathrm{C}$

\section{REFERANCES}

A.O.A.C. (2000). Official Methods of Analysis, $17^{\text {th }}$ Ed. Association of Official Analytical Chemists, Washington, D.C., USA.

Abril ,M. Campo, A. , Onenc,C., Alberti,P. and Negueruela, A-I, (2001). Beef colour evaluation as a function of ultimate $\mathrm{PhD}$. Meat science 58-69-78

Adms,.R. (2001). Identification of essential oils compounds by gas chromatography guardurpole. Mass spectrometry carol steam. Allured publishing crop.

Agunbide, S., Akintobi,O.and Ighodara ,O. (2010) . Some biochemical and organoleptic changes due to microbial growth in minced beef packaged in aluminum polyethelene trays and stored under chilled conditions. life science Journal , 7 (2) , 47- 51 .

Ali, A,F (2010). Antioxidative effect of pomposia extract on lipid oxidation and quality of ground beef during refrigerated storage. Electronic Journal of environmental, Agricultural and Food Chemistry 9 (5) ,918-930.

APHA (2001) . Compendium of method of microbiological examination of foods $4^{\text {th }}$ Ed. American Public Health Association .Inc. Washington D.C

Bell, W.N. and Shelef, L.A. (1987 ) . Availability of fat level and cooking methods on sensory and textural properties of ground beef patties .J.FoodSci43 (2) : 315-318.

Burt ,S. (2004) . Essential oil their antimicrobial properties and potential applications in foods -a review . Inter.J. OF Food Microbiology . , 94 :223253 .

Cross, H.R, Moen,R. and Slafield, M. (1978). Training and testing judges for sensory analysis of meat quality . Food technology,32-48- 52 .

Decker, E.A. (1995). The role of Phenolic, conjugated linoleic acid, carnosine and pyrroloquinone as non essential dietary antioxidants. Nutr. Res. (53)- 49-58. 
Fabian,D. ; Sabol,M. ; Domaracka,K. and Bujank,D.(2006). Essential oils, their antimicrobial against E.coli and effect on intestinal cell validity.Toxicology in vitroJ 20:1453-1445.

Fasseas, M.K., Mountzouris, K.C., Tarantilis, P.A., Polissiou, M.and Zervas, G. (2008.) Antioxidant activity in meat treated with oregano and sage essential oils. Food Chem. 106(3), 1188-1194.

Fik, M.K,.Surowda, K. and Firek ,B. ., (2008) . Properties of refrigerated ground beef treated with potassium lactate and sodium diacetate .J.Sci.Food Agric, 88 - 91-99.

Frankel , E.N. (1998) . Foods . In lipids oxidation volume 10 the oily press lipid library, 187-226. Glasgow, Scotland: Bell, Bain Ltd .

Hakki,A.Murat,E. ,Sigfrie,N. and Kollmannsberger, H. (2007) .Chemical composition and content of essential oil from the bud of cultivated clove (Zyzgium aromaticum ) Bio resources 2(2): 265:269.

Ismail H.A., Lee, K.Y, Ko ,H.D and Ahn,D.U. (2009) . Effect OF lipid application methods on the colour, lipid oxidation and volatiles of irradiated ground beef. J. of .Fd .Science, 74 (1) 25 - 32.

Juliani, H.R. and Simon, J.E.( 2002). Antioxidant of basil. Trends in new crops and new uses. In Janick, J. and Whipkey (eds.). ASHS Press, Alexandra, p 575-579.

Kandeepan ,G., Anjaneyulu,N. and Kondaiah ,N. (2011 ). Evaluation of quality and shelf life of buffalo meat keema at refrigerated storage . J. of Food Sci. Tech. 3, 454-463

Karpinska, M., Borowski, M., and Jung , M. (2001). The use of natural antioxidants in ready to serve food. Food chemistry (72)- 5-9.

Kim , S.Y., J.H., Kim, , M. and Danowska, M.J (1994). Antioxidants Activities of selected Oriental herbs extracts. JAOCS (71)- 663-640 .

Lee, G.B., Hendricks D.G. ,andCornforth ,D.P.( 1998). Antioxidant effects of carnosine and phytic acid in model beef system. J. of Food Science. 63-394398.

Martin,F.R. Frutos ,M.J. Perez-Alvarez,J.and Rio,J (2002). Flavonids as nutercutical: Structural related antioxidants properties and their role on ascorbic acid preservation .In;ATTA-Ur-Rahman(Ed.)Studies in natural products chemistry . $26: 324-389$, Amsterdam : Elsevier science .

Mau ,L.J. ,C.N.. , Chang, S.J. and Hung C.C., (2004). Antioxidant properties of methanolic extracts from Gifola frondosa, Marchella esculenta and Terminotomyces albuminous mycella. Food Chemistry, 94:415-419.

Niki, E. (1991) Action of ascorbic acid as a scavenger of active and stable oxygen radicals. American Journal of Clinical Nutrition, 54,1119s-1124s.

Oke ,F. , Aslin,A. , Ozturk, O. and Alundag, A. (2009 ). Essential oil compostion, antimicrobial and antioxidants activity of Sturegea cunefolia,Food Chemistry. 112-878-879. 
Orav, A. and Kann, J (2001 ). Determination of peppermint and orange aroma compounds in food and beverages . Proc. Estonian Acad. Sci. Chem., 2001, 50, 4, 217-225.

Pearson, D.(1986). Application of the chemical methods for the assessment of beef quality. II - Methods related to protein breakdown, J.Sci.Fd.Agric. 19 (7)366.

Raharjo, S. and Sofos, N. ( 1993 ). Methodology for measuring malonaldhyde as a product of lipid peroxidation in muscle tissues : A review . Meat Science, 35:135- 169.

Salem ,M.A. Amin,R.A.and Afifi,G.A (2010 ). Studies on antimicrobial and antioxidant efficiency of some essential oils in minced beef. Journal of American science, 6 (12) 691- 700 .

Salih,H.H. (2009 ). Effect of ascorbic acid with either $\alpha$-Tocopherol or Zizyphus spina chrisiti extracts on meat colour and lipids stability of fresh beef meat during cold storage. Alex J.Fd Sci. and Tech. , 6,1:9 .

Sasidharan,I and Nirmala,M. (2010) . Comparative chemical composition and antimicrobial activity fresh and dry ginger oil (zingiber officinale roscoe ) . International journal of current pharmaceutical research. 2 ( 4) ,40-43.

Skandamis,P.N.and Nychas, G.E (2001) . Effect of oregano essential oil on micro biological and physico-chemical attributes of minced meat stored in air and modified atmosphere . Journal of applied Microbiology ,91,1011-1022.

Solomakas, N. ,Gavaris ,A. , Kodis, P.and Botsogolou,N. (2008) . The antimicrobial, resin and their combination against Escherichia coli O157 :H7in minced beef during refrigerated storage . Meat Science, 80:159- 166 .

SPSS, (2007). Statistical Package for Social Science program version 17 for Windows, SPSS Inc, Chicago, IL, USA.

Tarladgis ,B.G.,Wattas ,B.M. ,Younathan ,M.T. and Dugan L.R. (1960 ) .A distillation method for the quantitative determination of malonaldhyde in rancid food .IAOCS $37: 403-406$.

Waskmundzka, M. ; Wianowska, D. ; Szewczyk, K. and Oniszczuk, A. (2007). Effect of sample-preparation methods on the HPLC quantitation of some phenolic acids in plant materials. Acta Chromatographica (19)- 227-237.

Wojdylo A. ; Oszmianski J. and Czemerys R. ( 2007). Antioxidant activity and phenolic compounds in 32 selected herbs . Food Chemistry 105, 490-494.

Zeyada, N., Zeitoun M. and Barbary O. (2007). Extraction, Identification and evaluation of antioxidant activity in some herbs and spices .Alex.J.Fd.Sci, and Technology .

Zheng W. and Wang Y. ( 2001) . Antioxidant activity and Phenolic compounds in selected herbs. J.Agric . Food Chem. 49,5165-5170. 


\section{تأثير إضافة الزيوت العطرية المستخلصة هن القرنفل والرنجبيل والنعناع لإطالة فترة صلاحية الحوم المفروهة المبردة}

هانيا إبراهيم الجمال ه وعفاف هانم محمود رمضان ه

• • قسم الصناعات الغذائية - كلية الزراعة- جامعة المنصورة- مصر

• هـسم الاقتصاد المنزلي- كلية التربية النوعية-جامعة المنصورة- مصر

\section{|الآنص الهزبي}

اجـري هــا البـحـث بغـرض دراسـة تـاثير اضـافة زيـوت الاعشـاب الطبيعيـة ( الزنجبيـل القرنفل- النعناع الاخضر ) لاطالة فترة صلاحية اللحسوم المفرومـة المبردة ـ حيث تم معاملـة لحسوم

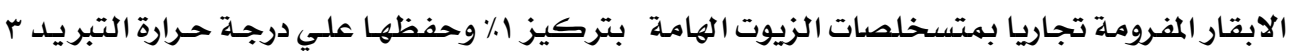

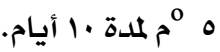

اوضحت نتائج GC-MASS احتواء زيـوت الاعشاب علسي كميـات عديـدة مـن المركبـات

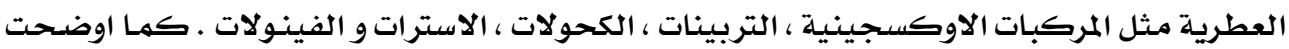

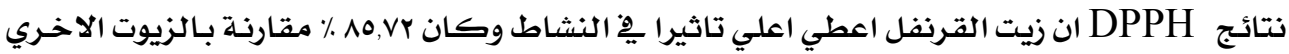

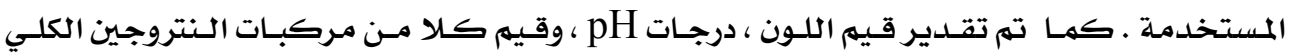

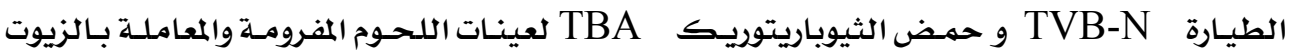

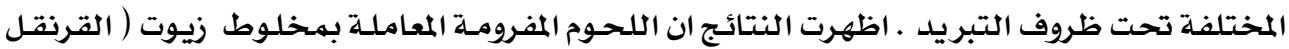

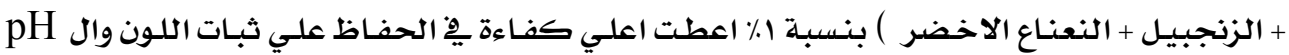
وتقليل تحلل البروتين واكسدة الـدهن خـلال فترة التخـزين مقارنـة بعينـات اللحسوم المعاملـة الاخـري

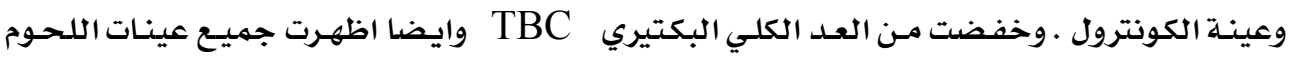

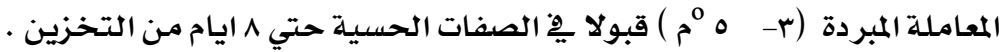
ومن النتائج المتحصل عليها اتضح ان المركبـات العطريـة الموجـودة بالزيوت المستخلصة لها تاثير مرتفع كمضاد اكسدة يقلل تكوين مركبات الاكسدة الثانوية وتكوين الامونيا مـع المحافظـة

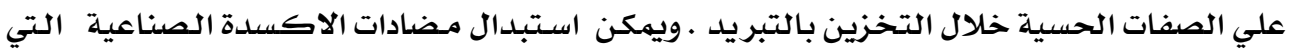
تستخدم اثناء تصنيع منتجات اللحوم بمستخلصات الزيوت العطريية . 